DOI 10.23859/2587-8344-2019-3-3-2

УДК 94 (47) «1906/1910»:002.2

Крылова Елена Николаевна

Кандидат исторических наук, доцент, Ленинградский государственный университет

им. А.С.Пушкина

(Санкт-Петербург, г. Пушкин, Россия) hellennak@yandex.ru

Krylova, Elena

Candidate of Historical Sciences, Associate Professor, Pushkin Leningrad State University

(St Petersburg, Pushkin, Russia) hellennak@yandex.ru

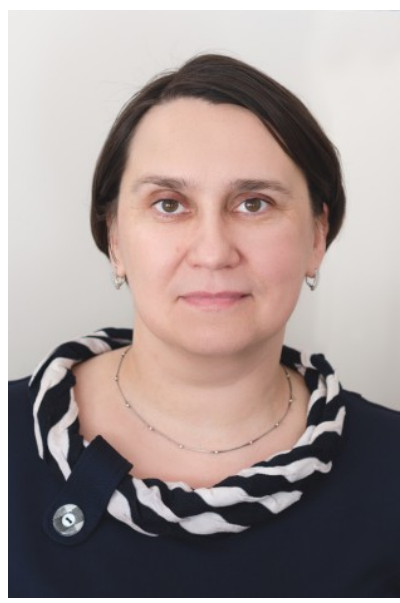

На государственной службе: к вопросу о незаконной деятельности Осведомительного бюро Главного управления по делам печати накануне крушения Российской империи *

\title{
In the Public Service: on the Issue of the Illegal Activities of the Information Bureau of the Main Directorate for Press Affairs on the Eve of the Collapse of the Russian Empire
}

Аннотащия. Статья посвящена неправовым аспектам деятельности Осведомительного бюро Главного управления по делам печати Министерства внутренних дел. Созданное в 1906 г. с целью налаживания двухсторонней коммуникации между органами власти и средствами массовой информации Осведомительное бюро реализовывало важные функции информирования субъектов коммуникации и снижения коммуникационных шумов при передаче сообщений от отправителя к получателю информации. Выполняя значительный объем работы по обеспечению коммуникаторов достоверной информацией, сотрудники Осведомительного бюро по роду своих полномочий имели доступ к разнообразным сведениям, в том числе имеющим гриф «государственная тайна». Владение информацией

* Для цитирования: Крылова E.H. На государственной службе: к вопросу о незаконной деятельности Осведомительного бюро Главного управления по делам печати накануне крушения Российской империи // Historia Provinciae - Журнал региональной истории. - 2019. T. 3. - № 3. - C. 884-910. DOI: 10.23859/2587-8344-2019-3-3-2

For citation: Krylova, E. "In the Public Service: on the Issue of the Illegal Activities of the Information Bureau of the Main Directorate for Press Affairs on the Eve of the Collapse of the Russian Empire." Historia Provinciae - The Journal of Regional History, vol. 3, no. 3 (2019): 884910, http:// doi.org/10.23859/2587-8344-2019-3-3-2

(C) Крылова Е.Н., 2019

(C) Krylova E., 2019 
подобного рода, а также некоторые личные качества сотрудников становились причинами разглашения секретных сведений в средствах массовой информации. Статья написана на основе архивного материала о незаконной деятельности Осведомительного бюро Главного управления по делам печати, хранящегося в Российском государственном историческом архиве.

Ключевые слова: Первая российская революция, Главное управление по делам печати, министерство внутренних дел, Осведомительное бюро, печать, общественное мнение, коррупция, незаконная деятельность.

Abstract. The article is devoted to the unlawful aspects of work of the Information Bureau of the Main Directorate for Press Affairs of the Ministry of Internal Affairs. Formed in 1906 in order to establish two-way communication between the authorities and the media, the Information Bureau implemented important functions of informing the participants of communication and reducing communication noise while passing on the information from the sender to the recipient. While carrying out a considerable amount of work to provide communicators with reliable information, the employees of the Information Bureau had access to information of different kinds, including that which was classified as state secret. Such awareness and also some personal characteristics of the employees became the reasons for disclosing secret information in the media. The article is based on the archival materials on the illegal activities of the Information Bureau of the Main Directorate for Press Affairs of the Ministry of Internal Affairs, which are kept in the Russian State Historical Archive (RGIA).

Key words: The First Russian Revolution, the Main Directorate for Press Affairs, the Ministry of Internal Affairs, the Information Bureau, the press, public opinion, corruption, illegal activities

\section{Введение}

Начало XX в. ознаменовалось Первой российской революцией. Требования общества к власти о свободе печати, вероисповедания, расширении круга деятельности земских и городских учреждений, нереализованные в ходе работы по исполнению Указа 12 декабря 1904 г. ${ }^{1}$, нашли свое воплощение в Манифесте 17 октября 1905 г. Обнародование Манифеста и дарование свободы слова, отмена цензуры и значительное облегчение процесса открытия периодических изданий, привели к росту числа средств массовой информации. Власть, утратившая старые способы контроля за печатью, вынуждена была адаптироваться к новым реалиям и начать использовать другие рычаги влияния на информационное пространство. В условиях появления большого количества частных средств массовой информации различного политического направления, подбор и интерпретация фактов в которых во многом определялись политической направленностью и капиталом, стоящим за организацией издания, образу власти и

${ }^{1}$ Крылова Е.Н. Петр Дмитриевич Святополк-Мирский и деятельность Министерства внутренних дел: автореф. дис... канд. ист. наук. - Санкт-Петербургский государственный университет, 2006. 
ее престижу наносился существенный ущерб, поскольку в погоне за читателем периодические издания могли публиковать непроверенную сенсационную информацию.

Вопрос изучения функционирования центральных государственных учреждений и построения эффективной коммуникации привлекает современных исследователей. Среди трудов, посвященных организационно-правовым основам деятельности Главного управления по делам печати министерства внутренних дел, следует отметить работы А.В. Амбросьева ${ }^{2}$. Важные моменты деятельности Осведомительного бюро при Главном управлении по делам печати рассмотрены в статьях В.Е. Кельнера ${ }^{3}$ и Е.Н. Крыловой ${ }^{4}$. Ряд аспектов работы Главного управления по делам печати изучен в исследованиях В.В. Шевцова ${ }^{5}$ и

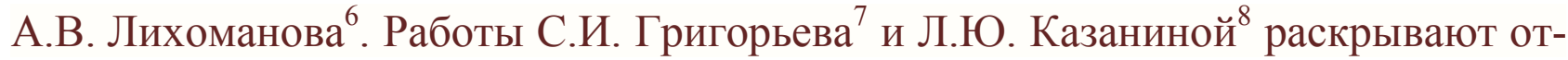
дельные стороны формирования общественного мнения о власти.

${ }^{2}$ Амбросьев А. В. Организационно-правовые основы деятельности Главного управления по делам печати Министерства внутренних дел Российской империи (1865-1917 гг.): автореф. дис... канд. юр. наук. - Академия управления министерства внутренних дел Российской Федерации, 2012; Амбросьев А.В. Организационно-правовые основы деятельности осведомительного бюро при Главном управлении по делам печати Российской империи // Соблюдение законности и обеспечение правопорядка в деятельности органов внутренних дел: сборник трудов межвузовского научного семинара. - Москва: Академия управления министерства внутренних дел Российской Федерации, 2011. - С. 5-9; Амбросьев А.В. Осведомительное бюро при Главном управлении по делам печати МВД Российской империи: структура и организация деятельности // История государства и права. - 2011. - №17. - С. 30-35.

${ }^{3}$ Кельнер В.E. Создание и деятельность осведомительного бюро при Главном управлении по делам печати: 1906-1917 гг. // Цензура в России: история и современность. - СанктПетербург: Российская национальная библиотека, 2011. - Вып. 5. - С. 237-243.

${ }^{4}$ Крылова Е.Н. Формирование положительного общественного мнения о государственной власти в России в 1906-1907 гг. (на примере работы Осведомительного бюро) // Частное и общественное в повседневной жизни населения России. История и современность / под редакцией В.А. Веременко. - Санкт-Петербург: Ленинградский государственный университет им. А.С. Пушкина, 2018. - Т. 1. - С. 162-167.

${ }^{5}$ Шевцуов В.В. Правительственная периодическая печать Сибири (вторая половина XIXначало XX в.). - Томск: Томский университет, 2016.

${ }^{6}$ Лихоманов А. В. Самодержавие в борьбе за общественное мнение в годы Первой русской революции: (Правительственная печать в 1905-1907 гг.): автореф. дис. ... канд. ист. наук. - Санкт-Петербургский государственный университет, 1995; Лихоманов А.В. Борьба самодержавия за общественное мнение в 1905-1907 гг. - Санкт-Петербург: Российская национальная библиотека, 1997.

${ }^{7}$ Григорьев С.И. Придворная цензура и образ верховной власти, 1831-1917. - СанктПетербург: Алетейя, 2007.

${ }^{8}$ Казанина Л. Ю. Столыпинские реформы в оценке российского общественного мнения (1906-1911): [к 150-летию со Дня рождения Петра Аркадьевича Столыпина]. - Москва: ACADEMIA; Академия повышения квалификации и профессиональной переподготовки работников образования, 2012. 
Вопросам дискредитации противника и борьбы за общественное мнение посредством печати посвящена работа А.Н. Егорова ${ }^{9}$. Говоря о предвыборных кампаниях в Государственную думу, автор анализирует приемы, используемые для дискредитации противника: «от утрирования мыслей, передергивания фактов и высмеивания до прямой лжи и клеветы» ${ }^{10}$. Данная работа позволяет понять общественно-политическую обстановку, в условиях которой функционировало Осведомительное бюро.

Среди исследователей, изучавших должностные преступления в России, отметим работы В.В. Астанина ${ }^{11}$, Е.И. Головиной ${ }^{12}$, М.В. Шедия ${ }^{13}$. При известной содержательности работ, указывающих на законодательные акты и случаи превышения должностных полномочий в Российской империи, вопрос о незаконной деятельности Осведомительного бюро Главного управления по делам печати министерства внутренних дел не затрагивался ${ }^{14}$, что позволяет автору статьи говорить о новизне данной темы.

Среди зарубежных трудов, посвященных истории России начала XX в., отметим ряд работ, имеющих прямое отношение к теме исследования, однако, не отличающихся глубиной изучения вопросов взаимодействия власти и прессы ${ }^{15}$.

9 Егоров А.Н. Предвыборная агитация как инструмент дискредитации политического противника (по материалам выборов в Государственную думу Российской империи) // Вестник Пермского университета. 2015. - Серия: История. - № 3 (30). - С. 170-178.

10 Егоров А.Н. Предвыборная агитация как инструмент дискредитации политического противника (по материалам выборов в Государственную думу Российской империи). C. 176.

${ }^{11}$ Астанин В.В. Борьба с коррупцией в России XVI - XX веков: диалектика системного подхода. - Москва: Российская криминологическая ассоциация, 2003.

${ }^{12}$ Головина Е.И. Правовые основы борьбы с коррупцией в России в XVI - XIX вв. - Москва: Министерство внутренних дел России, 2004.

${ }^{13}$ Шедий М.В. Коррупция в России: опыт концептуализации и механизмы противодействия. - Орел: Орловская региональная академия государственной службы, 2011.

${ }^{14}$ Кузовков Ю.В. История коррупции в России: В 2 т. - Москва: Анима-пресс, 2010; Подройкина И.А. Система уголовных наказаний в истории России и в современном зарубежном законодательстве. - Москва: Юстицинформ, 2017; Гольцов В.Б. Социальные основы предупреждения коррупции в правоохранительных органах России. - Самара: Самарская гуманитарная академия, 2014; Сторчилова Н.В. Коррупция в органах внутренних дел и ее предупреждение. - Москва: Всероссийский научно-исследовательский институ МВД России, 2012; Журавлева Я.А., Моисеев В.В. Борьба с коррупцией в России и мире. - Москва: Филиал Московского института экономики, менеджмента и права, 2011; Чашин А.Н. Коррупция в России: стратегия, тактика и методы борьбы. - Москва: Дело и сервис, 2009; Мысловский Е. H. Коррупция в России: преступление или образ жизни? - Москва: Экон-Информ, 2007.

${ }^{15}$ Lowe N. Mastering twentieth-century Russian history. - New York: Palgrave Macmillan, 2002; Weeks T. R. Across the revolutionary divide: Russia and the USSR. 1861-1945. - Chichester: Wiley-Blackwell, 2011; Competing voices from the Russian Revolution / ed. by M.C. Hickey. Santa Barbara, CA: Greenwood, 2011; Sunderland W. The baron's cloak: a history of the Russian 
В настоящей статье акцент сделан на противозаконных аспектах взаимодействия Осведомительного бюро Главного управления по делам печати министерства внутренних дел с периодической печатью.

\section{Основная часть}

В условиях Первой российской революции, в августе 1906 г. по инициативе председателя Совета министров П.А. Столыпина было создано Осведомительное бюро при Главном управлении по делам печати министерства внутренних дел. Идея была позаимствована из западноевропейского опыта, где власть взаимодействовала со средствами массовой информации через пресс-бюро. Ocведомительное бюро должно было стать связующим звеном между властью и обществом. Осуществление двухстороннего информирования предполагалось производить путем сбора и обработки сведений из государственных учреждений и периодической прессы. Для руководителей центральных органов власти была налажена система газетных вырезок по актуальным вопросам возглавляемых ими учреждений.

В обязанности Осведомительного бюро входило обслуживание

официальных, официозных и частных повременных органов печати достоверными, подлежащими оглашению, сведениями, касающимися предположений, действий и деятельности Правительства, правительственных и административных лиц и учреждений, а равно и главенствующих факторов общественно-политической жизни России и заграницы ${ }^{16}$.

Предоставляемые сведения также включали опровержения и пояснения «циркулирующих слухов и сообщений русской, инороднической и иностранной печати» ${ }^{17}$.

В целях обеспечения оперативного информирования печати Осведомительное бюро выпускало ежедневные бюллетени, на которые были подписаны столичные и провинциальные газеты, а для своевременного информирования правительства о сообщениях печати была создана система газетных вырезок. Кроме председателя Совета министров данные вырезки доставлялись всем министрам и начальникам главных управлений, в случае если газетные сообщения ка-

empire in war and revolution. - Ithaca: Cornell university press, 2014; Rendle M. Defenders of the Motherland: the Tsarist elite in revolutionary Russia. - Oxford: Oxford university press, 2010; Stone B. The anatomy of revolution revisited: a comparative analysis of England, France, and Russia. - Cambridge; New York: Cambridge university press, 2014; Стейнберг М. Великая русская революция. 1905-1921 / перевод с английского Н. Эдельмана; под научной редакцией М. Гершзона. - Москва: Институт Гайдара, 2018.

${ }^{16}$ Российский государственный исторический архив (РГИА). - Ф. 776. - Оп. 32. - Д. 213. - Л.1.

${ }^{17}$ РГИА. - Ф. 776. - Оп. 32. - Д. 213. - Л. 1. 
сались их учреждений. На сотрудников бюро возлагалась обязанность проверки слухов и сообщений печати. Ежедневно сотрудники Осведомительного бюро должны были посещать распределенные между ними правительственные учреждения с целью получения информации о деятельности правительства для публикации этих сведений в бюллетенях Осведомительного бюро, а также для составления необходимых опровержений по поводу сообщаемых газетами неверных или искаженных фактов ${ }^{18}$.

Так, с 7 по 30 мая 1907 г. Осведомительное бюро подготовило 58 официальных опровержений - в среднем по два опровержения в день. Из них с резолюцией «неверно» - 10, «вымысел» - 17, сообщения с разъяснениями по поводу статей и заметок - 20. Каждое третье опровержение обосновывалось, посылался запрос в управление или министерство и давался развернутый ответ, иногда занимающий около половины всего бюллетеня. По мнению Осведомительного бюро, в этот период 19 газет опубликовали ложную информацию. Соответственно было подготовлено следующее количество опровержений: для газеты «Товарищ» - 15, «Русь» - 10, «Речь» - 4, «Биржевые ведомости» - 3, «Русское слово» - 2, «Парус» - 2, «Петербургский листок» -2 , «Современная речь» -2 , «Новое время» $-2^{19}$.

В сентябре 1906 г. на момент начала работы штат Осведомительного бюро включал в себя 22 сотрудника: заведующий бюро, старший и младший помощники заведующего, секретарь и три помощника секретаря, шесть старших и пять младших сотрудников и четыре курьера. Заведующим бюро был назначен Николай Дмитриевич Грибоедов, «опытный журналист, много лет заведовавший отделом информации в газете «Новое время»» ${ }^{20}$. Как отмечено в личном деле Н.Д. Грибоедова, «организация Осведомительного бюро... вызвала усиленные хлопоты, причем г. Грибоедов проявил совершенно исключительную энергию, которая и дала возможность без всяких особых затрат со стороны казны поставить в сравнительно короткий срок столь трудное дело» ${ }^{21}$.

В Российском государственном историческом архиве, в деле о реорганизации Осведомительного бюро, хранится список сотрудников Осведомительного бюро с указанием обслуживаемых ими ведомств и учреждений, с обозначением числа обязательных посещений ${ }^{22}$, составленный на 10 января 1913 г. Данный документ позволяет получить представление об объеме работы в Осведоми-

${ }^{18}$ Бельгард А.В. Воспоминания. - Москва: Новое литературное обозрение, 2009. - С. 299.

${ }^{19}$ Крылова Е.Н. Формирование положительного общественного мнения о государственной власти в России в 1906-1907 гг. (на примере работы Осведомительного бюро). - Т. 1. C. 164 .

${ }^{20}$ Кельнер В.Е. Создание и деятельность осведомительного бюро при Главном управлении по делам печати: 1906-1917 гг. - С. 239.

${ }^{21}$ РГИА. - Ф. 776. - Оп. 23. - Д.50. - Л. 3 об.

${ }^{22}$ РГИА. - Ф. 776. - Оп. 33. - Д. 162. - Л. 106-111. 
тельном бюро. Так, на сотрудников, состоящих для поручений, приходилось около 13 отделов и департаментов правительственных учреждений и 26 посещений в неделю. Старшие сотрудники Осведомительного бюро посещали от 8 до 12 управлений и канцелярий от 17 до 26 раз в неделю. Младшие сотрудники обслуживали от 6 до 8 канцелярий, управ и контор, по 19 посещений в неделю на сотрудника.

Наибольшее количество посещений в неделю приходилось: в Государственную Думу, Канцелярию министерства императорского двора, Конторы великокняжеских дворов, Главное управление по делам местного хозяйства - по 6, в Канцелярию министра путей сообщения, Государственную канцелярию, Управление Главного врачебного инспектора, Канцелярию Святейшего Синода, Правительствующий Сенат, Санкт-Петербургское городское общественное управление и Канцелярию Санкт-Петербургского градоначальника - по 4.

По данным Осведомительного бюро в среднем в день производилось следующее количество работ:

а. обследуется вырезок для направления в ведомства от 500 до 600, б. наводится справок - на предмет разъяснений или опровержений от 18 до 20, в. составляется сообщений для официального и неофициального информирования печати и для сведения - ориентировки $-45-46^{23}$.

По состоянию на 1 июня 1914 г. за 5 месяцев, с 1 января 1914 г., Осведомительным бюро было дано для печати 2434 официальных сообщения в официальных бюллетенях и 968 неофициальных сообщений в бюллетенях «Бюро русских журналистов» ${ }^{24}$. В среднем 680 сообщений в месяц, из них -487 официальных. Из 2434 официальных сообщений 534 приходилось по министерству внутренних дел, 181 - по министерству финансов, 163 - по военному ведомству, 157 - по министерству путей сообщения, 131 - по совету министров. Наименьшее количество сообщений за 5 месяцев было дано по Государственному контролю и Государственной канцелярии - 1 .

Таким образом, представленные данные позволяют говорить о значительном объеме работы Осведомительного бюро, сотрудники которого проводили мониторинг средств массовой информации, осуществляли запросы в соответствующие учреждения для официальных разъяснений, подготавливали официальные сообщения для прессы и были осведомлены о текущей работе министерств и настроениях прессы. Уникальность получаемой информации и еe доступность порой вызывали искушение воспользоваться ей в корыстных целях для улучшения собственного благополучия.

\footnotetext{
${ }^{23}$ РГИА. - Ф. 776. - Оп. 33. - Д. 162. - Л. 111.

${ }^{24}$ РГИА. - Ф. 776. - Оп. 33. - Д. 162. - Л. 112.
} 
В мае 1910 г. на заведующего Осведомительным бюро Н.Д. Грибоедова и его помощника Н.X. Полномочного поступила жалоба с обвинением в незаконной деятельности. Записка начиналась с утверждения, что в 1908 г. заведующим Осведомительным бюро при Главном управлении по делам печати Николаем Дмитриевичем Грибоедовым было отдано распоряжение сотрудникам бюро доставлять негласные сведения о деятельности центральных правительственных учреждений. Эти секретные сведения не могли быть включены в рассылаемые Осведомительным бюро ежедневные бюллетени, но, по заявлению Н.Д. Грибоедова, были ему необходимы, «чтобы осведомлять Председателя Совета Министров статс-секретаря П.А. Столыпина» и самому постоянно «быть в курсе дел» ${ }^{25}$.

Во второй половине 1909 г. помощником заведующего Осведомительным бюро был назначен Николай Христианович Полномочный. Приступив к исполнению обязанностей, он стал требовать от сотрудников бюро предоставления ему секретных сведений, в виде ежедневных рапортов обо всем слышанном, с указанием должностных лиц, с которыми сотрудники вели беседы. Через некоторое время сотрудники Осведомительного бюро обратили внимание, что собранные ими секретные сведения стали попадать в левую печать и заграничные газеты. У них сложилось мнение, что Н.Д. Грибоедов и Н.Х. Полномочный, пользуясь своим служебным положением, продают эти секретные сведения. Для того, чтобы убедиться в своих предположениях, один из сотрудников, Н.А. Биндеман в конце 1909 г. подал Н.Х. Полномочному

рапорт с вымышленным известием о том, что начальник Главного Тюремного Управления действительный статский советник Хрулев израсходовал назначенные в пособие служащим 24000 рублей на разъезды свои и высших служащих Управления. И действительно, эти сведения вслед за тем появились в «Голосе Правды», «Речи» и других газетах ${ }^{26}$.

На деятельность Осведомительного бюро по сбору секретных сведений обратила внимание и правая печать. 11 января 1910 г. в газете «Земщина» появилась статья «Нет дыму без огня». Автор статьи, ссылаясь на парижского корреспондента газеты «Земщина», с недоумением спрашивал,

от кого и каким образом тайные документы, подчас первой государственной важности, попадают в руки революционного кагала за границей... Кто продает Россию и ее интересы ${ }^{27}$.

\footnotetext{
${ }^{25}$ РГИА. - Ф. 776. - Оп.32. - Д. 214. - Л. 1.

${ }^{26}$ РГИА. - Ф. 776. - Оп.32. - Д. 214. - Л. 1.

27 Земщина. - 1910. - 11 января. - № 183.
} 
При этом в статье рассматривались два аспекта: во-первых, автор отмечал, что «многие министерства и другие учреждения охотно делятся с сотрудниками официального учреждения, каковым является Осведомительное бюро, своими секретными сведениями» ${ }^{28}$. Однако в морском министерстве был получен отказ, в результате чего сотрудник Осведомительного бюро «явился в морское министерство с подлинныли секретными документами министерства иностранных дел, на которых имелись Высочайшие резолюции» ${ }^{29}$. Цель данного поступка состояла в предоставлении доказательств важности деятельности Осведомительного бюро. Сотрудник надеялся таким образом оказать психологическое давление на чиновников морского министерства и получить у них секретную информацию. О данном инциденте было доложено председателю Совета Министров П.А. Столыпину.

Во-вторых, автор статьи «Нет дыму без огня» обвинял Н.Х. Полномочного в совмещении сразу двух должностей: сотрудника газеты «Голос Правды» и заместителя заведующего Осведомительного бюро. На данное обвинение последовал быстрый ответ и уже в следующем номере было напечатано письмо в редакцию о том, что

бывший секретарь газеты «Голос правды», Н.Х. Полномочный 1-го ноября 1909 года сдал своему заместителю все находившиеся у него дела, а сотрудничество прекратилось с 1 ноября того же 1909 года и с тех пор никакого отношения к газете не имеет. Для тех же лиц, которые на основании нахождения фамилии г. Полномочного в числе сотрудников строят догадки о незаконном сотрудничестве его в газете, считаю долгом сообщить, что публикация о подписке на «Голос правды», на 1910 год была набрана 10 сентября 1909 г., т.е. тогда когда г. Полномочный еще из редакции не уходил $^{30}$.

Через две с половиной недели в газете «Земщина» появилась статья «Странное молчание» ${ }^{31}$. Автор статьи сетовал на то, что

прошло уже более недели после высказанных мною опасений о том, не через осведомительное ли бюро в нашу и заграничную печать проникают компрометирующие наше правительство сведения по делам негласного характера, а подчас и государственной важности (Земщина № 183). Осведомительное бюро хранит упорное молчание и по сие время ни словом не обмолвилось на это тяжкое подозрение. Невольно слагается убеждение, что заправилы бюро эту недозволенную отрасль деятельности сотрудников его, путем сообщения в печать негласных сведений по делам центральных учреждений, превратили в доходную для себя статью ${ }^{32}$.

\footnotetext{
28 Земщина. - 1910. - 11 января. - № 183.

29 Земщина. - 1910. - 11 января. - № 183.

30 Земщина. - 1910. - 12 января. - № 184.

31 Земщина. - 1910. - 31 января. - № 195.

32 Земщина. - 1910. - 31 января. - № 195.
} 
Признавая правомерность опровержения о возможности совмещения должностей Н.Х. Полномочным, автор вновь ставит под сомнение законность деятельности Осведомительного бюро:

Допускаю, что г. Полномочный более в «Голосе правды» не работает, но в таком случае позволю себе лишь спросить, из каких источников получены газетой следующие сведения: о 24.000 р., отпущенных начальнику главного тюремного управления Хрулеву на пособие низшим служащим и израсходованных им, будто бы, на командировки; о «рождественском гусе» чинов министерства путей сообщения; о «бездарном» директоре горного департамента Курмакове; о чиновнике министерства иностранных дел Горвице и некоторые другие появившиеся в газете под рубрикой «Вести и слухи» заметки?» и далее: «Если «Голос правды» пожелает воспользоваться бесспорным своим правом не называть авторов этих заметок, то пусть он подтвердит, что перечисленные заметки никакого отношения к Осведомительному бюро не имеют ${ }^{33}$.

Несмотря на то, что редакция газеты «Земщина» упрекала Осведомительное бюро в молчании, а руководство в бездействии, статьи все же произвели определенный эффект. После появления статей Осведомительное бюро посетил начальник Главного управления по делам печати А.В. Бельгард, который обратился к сотрудникам с речью, приблизительно следующего содержания:

Вы, господа, делаете великое государственное дело. Нарекания во всяком деле, так и в Вашем почти неизбежны. Но Вы этим не смущайтесь, за Ваши ошибки отвечаю я. Секретных сведений Вы не добывайте. Те, которые дают Вам эти сведения, знают, для чего они их Вам дают. Вы же их не принимайте... ${ }^{34}$

Однако, несмотря на беседу, сбор секретных сведений в Осведомительном бюро не прекратился. Секретная информация продолжала собираться сотрудниками, хотя уже не в таких размерах и не так открыто, как ранее. 9 мая 1910 г. Н.Д. Грибоедов поручил сотруднику Н.А. Биндеману собрать сведения о предполагаемом строительстве в Финляндии укреплений и казарм военного министерства. Однако сотрудник, которому это было поручено, боясь ответственности, отказался, о чем сообщил сослуживцам. Помимо сбора секретной информации, бесплатно сообщаемой Осведомительному бюро, материал записывался в расходные ведомости, как платный, на имя некоторых сотрудников. Секретарь Осведомительного бюро, знавший о ситуации, потратил подотчетные средства, прикрыв эти растраты подлогами, а заведующий Осведомительным бюро не поднял вопроса о привлечении его к уголовной ответственности.

\footnotetext{
33 Земщина. - 1910. - 31 января. - № 195.

${ }^{34}$ РГИА. - Ф. 776. - Оп. 32. - Д. 214. - Л. 2.
} 
Отметим, что деятельность государственных служащих регулировалась действующим законодательством, в частности, «Уложением о наказаниях» пятым разделом «О преступлениях и проступках по службе государственной и общественной». М.В. Шедий указывает, что

Уложение о наказаниях устанавливало достаточно жесткие санкции за неисполнение высочайшего указа или поведение с намерением для каких-либо корыстных или иных видов превышения власти, ... присвоение или растрату вверенного по службе казенного или частного имущества ${ }^{35}$.

Например, за получение непредусмотренного законом вознаграждения должностным лицом органов государственной власти, связанное с нарушением обязанностей по службе, оно подвергалось наказанию

в виде лишения свободы на срок от одного года до трех лет, ... при смягчающих вину обстоятельствах должностное лицо наказывалось судом строгим выговором или освобождением от занимаемой должности ${ }^{36}$.

\section{Можно согласиться с Е.И. Головиной, которая замечает, что}

с объективной стороны состав превышения власти характеризовался совершением действий, как выходящих за пределы компетенции должностного лица, так и таких, которые формально соответствовали служебной компетенции, но по существу противоречили интересам государства ${ }^{37}$.

В ситуации с Осведомительным бюро, на наш взгляд, как раз имело место превышение должностных обязанностей заведующим Осведомительным бюро и его помощником. Требуя от подчиненных сбора и предоставления секретной информации, руководители Осведомительного бюро, по сути, выходили за пределы своей компетенции и действовали в ущерб интересам государства.

Целый ряд сотрудников бюро (В.В. Добрешин, П.Р. Кук и В.А. Мясоедов) обращались к начальнику Главного управления по делам печати А.В. Бельгарду с устными и письменными жалобами на незаконную деятельность Н.Д. Грибоедова. Но расследования назначено не было ${ }^{38}$.

Объяснение этого бездействия власти, по мнению автора записки о незаконной деятельности Осведомительного бюро, следовало искать в слухах, при-

${ }^{35}$ Шедий М.В. Коррупция в России: опыт концептуализации и механизмы противодействия. - С. 52.

${ }^{36}$ Шедий М.В. Коррупция в России: опыт концептуализации и механизмы противодействия. - С. 53.

${ }^{37}$ Головина Е.И. Правовые основы борьбы с коррупцией в России в XVI-XIX вв. - С. 74.

${ }^{38}$ РГИА. - Ф. 776. - Оп. 32. - Д. 214. - Л. 2. 
писывающих Н.Д. Грибоедову роль поверенного в денежных делах А.В. Бельгарда. Автор утверждал, что Н.Д. Грибоедов при помощи действительного статского советника Н.В. Хлебникова, имеющего связи в финансовых сферах, неоднократно устраивал займы для А.В.Бельгарда ${ }^{39}$. Сам же Н.В. Хлебников до 25 мая 1910 г. являлся сотрудником Осведомительного бюро с жалованием 300 рублей в месяц, согласно окладам исполняющих обязанности помощников заведующего Осведомительным бюро ${ }^{40}$.

Таким образом, записка указывала на незаконный сбор секретных сведений, которые потом попадали в печать, на присвоение денежных средств и осуществление финансовых махинаций, а также бездействие вышестоящей власти. По мнению автора записки, начальник Главного управления по делам печати покрывал заведующего Осведомительным бюро.

Данная ситуация наглядно показывает состояние правительственного учреждения и настроения сотрудников Осведомительного бюро, находящихся на руководящих должностях. Обладая связями и властью, достаточной для получения ценной информации, вместо служения государственной системе, которую они были призваны защищать, и отстаивания в информационном поле ее интересов, чиновники использовали свое служебное положение для реализации личных интересов и обогащения, способствуя падению авторитета Осведомительного бюро и власти в целом.

Жалобы на деятельность бюро поступали, но судя по отсутствию документов о разбирательствах и факту, что смены начальства не произошло, можно сделать вывод о том, что служебного расследования не было. Н.Д. Грибоедов и его помощник продолжали работать в Осведомительном бюро, впрочем, как и сотрудники, которые выражали недовольство незаконной деятельностью руководства.

\section{Заключение}

Созданное для обеспечения прессы достоверными и подлежащими публикации сведениями, касающимися деятельности правительства, правительственных и административных лиц и учреждений, а также объективного освещения общественно-политической жизни России и заграницы, Осведомительное бюро функционировало на средства правительства. Выполняя государственный заказ по составлению опровержений и прояснению «циркулирующих слухов и сообщений русской, инороднической и иностранной печати» высокопоставленные сотрудники Осведомительного бюро, собирая и распространяя сведения, не подлежащие разглашению, сами становились распространителями слухов, наносящих ущерб престижу и авторитету власти. Данная ситуация была возможна

\footnotetext{
${ }^{39}$ РГИА. - Ф. 776. - Оп. 32. - Д. 214. - Л. 3.

${ }^{40}$ РГИА. - Ф. 785. - Оп. 1. - Д. 151. - Л. 84.
} 
при отсутствии контроля за деятельностью Осведомительного бюро со стороны вышестоящего руководства, начальника Главного управления по делам печати, в ведении которого находилось Осведомительное бюро, а также отсутствия отлаженной схемы контроля за деятельностью организации, сотрудников и нормативно-правовых норм контроля, закрепленных на законодательном уровне. Совокупность данных факторов вела к возникновению ситуаций, в которых государственный орган, созданный для поддержки существующей политической системы, сам же ее дискредитировал.

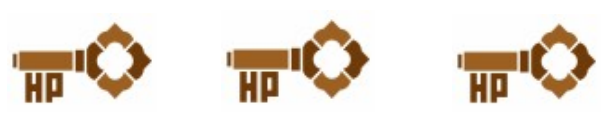

\section{Introduction}

The beginning of the $20^{\text {th }}$ century was marked by the First Russian Revolution. The demands of the public to the authorities on freedom of the press, religion, and expansion of the range of activities of rural and city institutions that had not been implemented during the execution of the Decree of December 12, 1904, were later embodied in the Manifesto of October 17, 1905. ${ }^{1}$ The publication of the Manifesto and the granted freedom of expression, the abolition of censorship and significant simplification of opening new periodicals resulted in an increase in the number of mass media. Having lost the old ways to control the press, the authorities were forced to adapt to the new realities and to start using other levers of influence on the information space. The emergence of a large number of privately owned mass media of various political lines, where the selection and interpretation of facts were largely determined by the political orientation and by the capital invested to open a periodical, impaired the image of the authorities and their prestige, because in pursuit of the readership periodicals could publish unverified sensational information.

The issue of studying the functioning of central public institutions and of establishing effective communication attracts modern researchers. Among the works devoted to the organizational and legal framework of the Main Directorate for Press Affairs of the Ministry of Internal Affairs, the works of A. Ambros'ev should be noted. ${ }^{2}$

${ }^{1}$ E.N. Krylova, Petr Dmitrievich Svyatopolk-Mirsky and the Activities of the Ministry of Internal Affairs [in Russian] (PhD thesis, St Petersburg State University, 2006).

${ }^{2}$ A.V. Ambros'ev, Organizational and Legal Bases for the Activities of the Main Directorate for Press Affairs of the Ministry of Internal Affairs of the Russian Empire (1865-1917) [in Russian] (PhD thesis. Academy of Management of the Ministry of Internal Affairs of the Russian Federation, 2012); A.V. Ambros'ev, "Organizational and Legal Bases for the Activities of the Information Bu- 
The articles by V. Kel'ner ${ }^{3}$ and E. Krylova ${ }^{4}$ discuss important points in the activities of the Information Bureau of the Main Directorate for Press Affairs. Some aspects of the work of the Main Directorate for Press Affairs were considered in the studies of V. Shevtsov ${ }^{5}$ and A. Likhomanov. ${ }^{6}$ S. Grigor'ev ${ }^{7}$ and L. Kazanina ${ }^{8}$ devoted their works to the study of individual aspects of shaping public opinion about the authorities.

The work of A. Egorov is devoted to the problems of discrediting the opponent and of the struggle for public opinion with the help of the press. ${ }^{9}$ Speaking about the election campaigns to the State Duma, the author analyzes the methods used to discredit the adversary, "from exaggerating thoughts, distorting facts and ridiculing, to direct lies and slander." 10 This work allows us to understand the social and political situation in which the Information Bureau operated.

reau of the Main Directorate for Press Affairs of the Russian Empire" [in Russian], in Observance of the Law and Ensurance of Law and Order in the Activities of Internal Affairs Authorities] (Moscow: Akademiya upravleniya Ministerstva vnutrennikh del Rossiiskoi Federatsii, 2011), 5-9; A.V. Ambros'ev, "The Information Bureau of the Main Directorate for Press Affairs of the Ministry of Internal Affairs of the Russian Empire: Structure and Organization of Activities" [in Russian], Istoriya gosudarstva i prava, no. 17 (2011): 30-35.

${ }^{3}$ V.E. Kel'ner, "Establishment and Operation of the Information Bureau of the Main Directorate for Press Affairs: 1906-1917" [in Russian], in Censorship in Russia: History and the Present, issue 5 (St Petersburg: Rossiiskaya natsional'naya biblioteka, 2011), 237-43.

${ }^{4}$ E.N. Krylova, "Forming Positive Public Opinion about the Governmental Authorities of Russia in 1906-1907 (Based on the Work of the Information Bureau" [in Russian], in Private and Public Affairs in the Daily Life of the Population of Russia. History and Modernity, ed. V.A. Veremenko, vol. 1 (St Petersburg: Leningradskii gosudarstvennyi universitet im. A.S. Pushkina, 2018): 162-67.

${ }^{5}$ V.V. Shevtsov, Governmental Periodical Press of Siberia (Second Half of the $19^{\text {th }}-$ Early $20^{\text {th }}$ Century) [in Russian] (Tomsk: Tomskii universitet, 2016).

${ }^{6}$ A.V. Likhomanov, Autocracy in the Struggle for Public Opinion during the First Russian Revolution (Governmental Press in 1905-1907) [in Russian] (PhD thesis. St Petersburg State University, 1995); A.V. Likhomanov, The Struggle of Autocracy for Public Opinion in 1905-1907 [in Russian] (St Petersburg: Rossiiskaya natsional'naya biblioteka, 1997).

${ }^{7}$ S.I. Grigor'ev, Court Censorship and the Image of Supreme Power, 1831-1917 [in Russian] (St Petersburg: Aleteya, 2007).

${ }^{8}$ L. Yu. Kazanina, Stolypin Reforms in the Assessment of Russian Public Opinion (1906-1911): [To the 150 ${ }^{\text {th }}$ Anniversary of the Birth of Petr Arkad'evich Stolypin] [in Russian] (Moscow: ACADEMIA; Akademiya povysheniya kvalifikatsii i professional'noi perepodgotovki rabotnikov obrazovaniya, 2012).

${ }^{9}$ A.N. Egorov, "Pre-Election Campaign as a Tool to Discredit a Political Opponent (Based on the Materials of Elections to the State Duma of the Russian Empire" [in Russian], Vestnik Permskogo universiteta. Seriya: Istoriya, no. 3(30) (2015): 170-78.

${ }^{10}$ Egorov, "Pre-Election Campaign," 176. 
Among the researchers who studied official misconduct in Russia, we should note the works of V. Astanin, ${ }^{11}$ E. Golovina, ${ }^{12}$ and M. Shedii. ${ }^{13}$ With a well-known pithiness of works devoted to legislative acts and cases of abuse of power in the Russian Empire, the question of illegal activities of the Information Bureau of the Main Directorate for Press Affairs of the Ministry of Internal Affairs has not been addressed, ${ }^{14}$ which allows the author of the article to speak about the novelty of this subject.

Among foreign works devoted to the history of Russia in the beginning of the $20^{\text {th }}$ century, let us note a number of works which pertain to the subject of research but do not give a deeper insight into the interaction between the authorities and the press. ${ }^{15}$

This article focuses on the illegal aspects of the interaction between the Information Bureau of the Main Directorate for Press Affairs of the Ministry of Internal Affairs and the periodical press.

${ }^{11}$ V.V. Astanin, The Fight against Corruption in Russia in the $16^{\text {th }}-20^{\text {th }}$ Centuries: Dialectics of System Approach [in Russian] (Moscow: Rossiiskaya kriminologicheskaya assotsiatsiya, 2003).

${ }^{12}$ E.I. Golovina, Legal Framework of the Fight against Corruption in Russia in the $16^{\text {th }}-19^{\text {th }}$ Centuries [in Russian] (Moscow: Ministerstvo vnutrennikh del Rossii, 2004).

${ }^{13}$ M.V. Shedii, Corruption in Russia: the Experience of Conceptualization and Counteraction Mechanism [in Russian] (Orel: Orlovskaya regional'naya akademiya gosudarstvennoi sluzhby, 2011).

${ }^{14}$ Yu.V. Kuzovkov, History of Corruption in Russia [in Russian], 2 vols. (Moscow: Animapress, 2010); I.A. Podroikina, The System of Criminal Penalties in the History of Russia and in Modern Foreign Legislation [in Russian] (Moscow: Yustitsinform, 2017); V.B. Gol'tsov, Social Foundations for the Prevention of Corruption in Law Enforcement Agencies of Russia [in Russian] (Samara: Samarskaya gumanitarnaya akademiya, 2014); N.V. Storchilova, Corruption in the Internal Affairs Bodies and Its Prevention [in Russian] (Moscow: Vserossiiskii nauchno-issledovatel'skii institut Ministerstva vnutrennikh del Rossii, 2012); Ya.A. Zhuravleva and V.V. Moiseev, Fight against Corruption in Russia and in the World [in Russian] (Moscow: Filial Moskovskogo instituta ekonomiki, menedzhmenta i prava v gorode Tula, 2011); A.N. Chashin, Corruption in Russia: Strategy, Tactics and Methods of Fight [in Russian] (Moscow: Delo i servis, 2009); E.N. Myslovskii, Corruption in Russia: a Crime or a Way of Life? [in Russian] (Moscow: EkonInform, 2007).

${ }^{15}$ N. Lowe, Mastering Twentieth-Century Russian History (New York: Palgrave Macmillan, 2002); T.R. Weeks, Across the Revolutionary Divide: Russia and the USSR. 1861-1945 (Chichester: Wiley-Blackwell, 2011); M.C. Hickey, ed., Competing Voices from the Russian Revolution (Santa Barbara, Calif.: Greenwood, 2011); W. Sunderland, The Baron's Cloak: A History of the Russian Empire in War and Revolution (Ithaca: Cornell University Press, 2014); M. Rendle, Defenders of the Motherland: The Tsarist Elite in Revolutionary Russia (Oxford: Oxford University Press, 2010); B. Stone, The Anatomy of Revolution Revisited: A Comparative Analysis of England, France, and Russia (Cambridge; New York: Cambridge University Press, 2014); M. Steinberg, The Russian Revolution, 1905-1921 [in Russian], transl. N. Edel'man, ed. M. Gershzon (Moscow: Institut Gaidara, 2018). 


\section{Main body}

Under the conditions of the First Russian Revolution, in August 1906, on the initiative of the chairman of the Council of Ministers P. Stolypin, the Information Bureau was established as a part of the Main Directorate for Press Affairs of the Ministry of Internal Affairs. The idea was borrowed from the Western European experience, where the authorities interacted with the media through a press bureau. The Information Bureau was supposed to be the link between the government and the public. The implementation of such two-way informing was supposed to be done by collecting and processing information from the public institutions and periodicals. For the heads of the central authorities, a system of newspaper clippings was developed, the clippings concerning the topical issues of the institutions they headed.

The responsibilities of the Information Bureau included:

Servicing official, para-govermmental, and private periodical press organs with reliable, publicly available information concerning the assumptions, actions and activities of the government, of state and administrative officials and institutions, as well as objective coverage of the dominating factors of social and political life in Russia and abroad. ${ }^{16}$

The information provided also included denials and explanations of "circulating rumours and reports from the Russian, non-Russian, and foreign press." 17

In order to provide the press with the latest update information, the Information Bureau issued daily newsletters, for which capital and regional newspapers were subscribed, and a system of newspaper clippings was established to timely inform the government about publications in the press. In addition to the chairman of the Council of Ministers, those clippings were delivered to all ministers and heads of main departments if the newspaper reports concerned their institutions. The Bureau employees had the responsibility to check rumours and press reports. Every day, the employees of the Information Bureau had to visit assigned to them government agencies in order to obtain information about the activities of the government to be published in the newsletters of the Information Bureau and to compile the necessary denials of false or misrepresented facts published by newspapers. ${ }^{18}$

Thus, from May 7 to May 30, 1907, the Information Bureau prepared 58 official denials, with an average of two denials per day. Of them, 10 were marked as false; 17 were marked as fiction; 20 were items explaining articles and notes. Every third denial was justified, an enquiry was sent to an administration or a ministry and a detailed reply was given that sometimes occupied about half of the newsletter. According to the Information Bureau, during this period, 19 newspapers published false in-

${ }^{16}$ F. 776, op. 32, d. 213, 1. 1. Rossiiskii gosudarstvennyi istoricheskii arkhiv [Russian State Historical Archive] (RGIA), St Petersburg, Russia.

${ }^{17}$ F. 776, op. 32, d. 213, 1. 1, RGIA.

${ }^{18}$ A.V. Bel'gard, Memoirs [in Russian] (Moscow: Novoe literaturnoe obozrenie, 2009), 299. 
formation. The following number of denials were prepared, correspondingly: 15 for the newspaper Tovarishch [Comrade]; 10 for Rus'; 4 for Rech' [Speech]; 3 for Birzhevye vedomosti [Stock exchange news]; 2 for Russkoe slovo [The Russian word]; 2 for Parus [Sail]; 2 for Peterburgskii listok [Petersburg leaflet]; 2 for

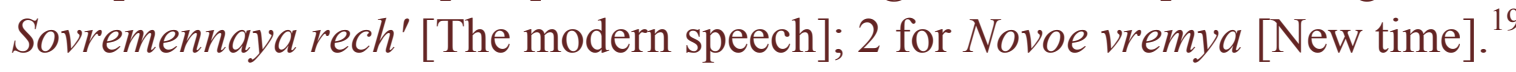

In September 1906, at the time of starting its work, the staff of the Information Bureau consisted of 22 employees: the head of the Bureau, a senior and a junior assistant to the head, a secretary and three secretary assistants, six senior and five junior employees, and four messegers. Nikolai Dmitrievich Griboedov, "an experienced journalist who had been in charge of the information department in the Novoe Vremya newspaper for many years," ${ }^{20}$ was appointed the head of the Bureau. As is pointed out in N. Griboedov's personal file, "the organization of the Information Bureau ... took much effort, but Mr. Griboedov showed exceptional energy, due to which it was possible to set going such a difficult work in such short time without any special costs for the treasury., 21

The file of the reorganization of the Information Bureau, which is kept in the Russian State Historical Archive, contains the list of employees of the Information Bureau as of January 10, 1913, indicating the departments and agencies they covered and the number of mandatory visits. ${ }^{22}$ This document makes it possible to get an idea of the amount of work done by the Information Bureau. For example, the employees who ran errands were to work with 13 divisions and departments of the government agencies and to make 26 visits per week. Senior employees of the Information Bureau visited from 8 to 12 administrations and administrative offices from 17 to 26 times a week. Junior employees services from 6 to 8 administrative offices, councils and offices and each of them was to make 19 visits a week.

The greatest number of visits per week fell at the State Duma, the Office of the Ministry of the Imperial Court, the Office of the Grand Duchy Courts, the Main Directorate for Local Economy Affairs (6 visits to each); the Office of the Minister of Communications, the State Chancellery, the Office of the Chief Medical Inspector, the Office of the Most Holy Synod, the Governing Senate, St Petersburg City Public Administration, the Office of the St Petersburg Mayor (4 visits to each).

According to the Information Bureau, the average number of activities per day was as follows:

(a) from 500 to 600 newspaper clippings are examined to be further sent to various government institutions; (b) from 18 to 20 inquiries are made for explanations or denials;

${ }^{19}$ Krylova, "Forming Positive Public Opinion about the Governmental Authorities of Russia," 164.

${ }^{20}$ Kel'ner, "Establishment and Operation of the Information Bureau," 239.

${ }^{21}$ F. 776, op. 23, d.50, 1.3 ob., RGIA.

${ }^{22}$ F. 776, op. 33, d. 162, 11. 106-111, RGIA. 
(c) 45-46 messages are compiled for official and unofficial information to the press and for reference. $^{23}$

As of June 1, 1914, for the period of 5 months beginning from January 1, 1914, the Information Bureau prepared for publication 2,434 official messages in the official newsletters and 968 unofficial messages in the newsletters of the Bureau of Russian Journalists. ${ }^{24}$ On average, that amounted to 680 messages per month, of which 487 were official. Out of 2,434 official reports, on the Ministry of Internal Affairs were 534; on the Ministry of Finance, 181; on the Military Department, 163; on the Ministry of Railways, 157; on the Council of Ministers, 131. The smallest number of messages (only 1) for the period of 5 months was issued on the State Control Office and the State Chancellery.

Thus, the data presented above suggests a significant amount of work done by the Information Bureau, whose staff monitored the media, made inquiries to the relevant institutions for official interpretations, prepared official press releases, and were aware of the current work of the ministries and attitudes of the press. The uniqueness of the information received and its accessibility were tempting enough to yield to the temptation now and then and to use the information for personal advantage in order to improve one's own well-being.

In May 1910, a complaint was filed against the head of the Information Bureau N. Griboedov and his assistant N. Polnomochnyi, accusing them of illegal activities. The text began with the statement that in 1908 the head of the Information Bureau of the Main Directorate for Press Affairs Nikolai Dmitrievich Griboedov ordered the Bureau employees to deliver secret information about the activities of central government agencies. That secret information could not be included in the daily newsletters of the Information Bureau but, according to N. Griboyedov, was necessary for him "to inform the chairman of the Council of Ministers, State Secretary P. Stolypin" and also "to be constantly in the know himself." 25

In the second half of 1909, Nikolai Khristianovich Polnomochnyi was appointed assistant to the head of the Information Bureau. On entering upon his duties, he started to demand that the Bureau employees should provide him with secret information in the form of daily reports on everything they had heard, indicating the officials they had talked to. After some time, the staff of the Information Bureau noticed that the secret information they had collected began to appear in the leftist press and in foreign newspapers. They formed the opinion that N. Griboedov and N. Polnomochnyi abused their official positions and sold that secret information. In order to verify

\footnotetext{
${ }^{23}$ F. 776, op. 33, d. 162, 1. 111, RGIA.

${ }^{24}$ F. 776 , op. 33, d. $162,1.112$, RGIA.

${ }^{25}$ F. 776, op. 32, d. 214, 1. 1, RGIA.
} 
those assumptions, at the end of 1909, N. Bindeman, one of the employees, submitted to N. Polnomochnyi a report.

A report with fictitious news that the head of the Main Prison Administration Active State Councillor Khrulev spent 24,000 roubles assigned to his employees' allowance for his personal traveling and that of his senior officers. And indeed, this information appeared afterwards in Golos Pravdy, Rech', and other newspapers. ${ }^{26}$

The right-wing press also paid attention to the efforts of the Information Bureau to collect secret information. On January 11, 1910, an article under the headline "There's no Smoke without Fire" appeared in the newspaper Zemshchina. Referring to the Paris correspondent of Zemshchina, the author of the article asked in perplexity:

From whom and how exactly do secret documents, sometimes of state importance, fall into the hands of the revolutionary crowd abroad? ... Who sells Russia and its interests? ${ }^{27}$

The article considered two aspects: first, the author noted that "many ministries and other institutions willingly shared their secret information with the employees of an official institution, and the Information Bureau was such an institution." ${ }^{28}$ However, a refusal was received at the Ministry of Maritime Affairs and an employee of the Information Bureau "came to the Ministry of Maritime Affairs with authentic secret documents of the Ministry of Foreign Affairs, which had the Highest instructions appended on them." ${ }^{29}$ The purpose of this act was to provide evidence of the importance of the Information Bureau activities. In this way the employee hoped to exert psychological pressure on the officials of the Ministry of Maritime Affairs and to receive secret information from them. This incident was reported to the chairman of the Council of Ministers P. Stolypin.

Secondly, the author of the article "There is No Smoke without Fire" accused N. Polnomochnyi of combining two positions at once: that at the newspaper Golos Pravdy and the position of the deputy head of the Information Bureau. This accusation was followed by a quick response, and the next issue of the newspaper published a letter to the editor stating the following:

The former secretary of the newspaper Golos Pravdy N.Kh. Polnomochnyi turned over all his duties and all his files to his deputy on November 1, 1909; his cooperation with the newspaper ended on November 1 of that same year 1909, and since then, he has had nothing to do with the newspaper. For those persons who speculate about Polnomochnyi's ille-

\footnotetext{
${ }^{26}$ F. 776, op. 32, d. 214, 1. 1, RGIA.

${ }^{27}$ Zemshchina, no. 183, January 11, 1910.

${ }^{28}$ Zemshchina, no. 183, January 11, 1910.

${ }^{29}$ Zemshchina, no. 183, January 11, 1910.
} 
gal cooperation with the newspaper on seeing his name in the list of employees, I consider it my duty to inform that the announcement about the subscription to the newspaper Golos Pravdy for 1910 was typeset on September 10, 1910, when Mr. Polnomochnyi had not still left the editorial office. ${ }^{30}$

After two and a half weeks, the article "Strange Silence" appeared in the newspaper Zemshchina." 31 The author of the article complained:

More than a week has passed after the concerns I expressed about the involvement of the Information Bureau in passing the compromising information on secret matters, and sometimes on matters of national importance, to domestic and foreign press (Zemshchina no. 183). The Information Bureau keeps stubborn silence and has not said a word about this serious suspicion so far. The conviction is involuntarily formed that, by reporting secret information on the affairs of central institutions to the press, the kingpins of the Bureau have turned this unlawful activity of their employees into a profitable business for themselves. ${ }^{32}$

Admitting the legitimacy of the denial that N. Polnomochnyi occupied two positions at once, the author questioned the lawfulness of the Information Bureau's activities again:

I can admit that Mr. Polnomochnyi does not work for Golos Pravdy any longer but, that being the case, I will only let myself ask what sources provided the newspaper with the following information: about 24,000 roubles allocated to the Head of the Main Prison Administration Khrulev as an allowance to his lower-ranking employees and spent by him on business trips; about the "Christmas goose" of the officials of the Ministry of Railways; about Kurmakov, the "inept" director of the mining department; about the official of the Ministry of Foreign Affairs Gorvitsa; and about some other items published under the heading "News and Rumours." And further: if Golos Pravdy wishes to use its undisputable right not to name the authors of those items, then let it confirm that the items listed above have nothing to do with the Information Bureau. ${ }^{33}$

Despite the fact that the editorial board of the newspaper Zemshchina accused the Information Bureau of silence, and its management, of inaction, the articles still made a certain effect. After the publication of those articles, the head of the Main Directorate for Press Affairs A. Bel'gard visited the Information Bureau and addressed its staff with a speech:

You, gentlemen, are doing a great job for the state. In any job, as well as in yours, complaints are almost inevitable. However, do not be embarrassed by that, I am responsible for

\footnotetext{
${ }^{30}$ Zemshchina, no. 184, January 12, 1910.

${ }^{31}$ Zemshchina, no. 195, January 31, 1910.

${ }^{32}$ Zemshchina, no. 195, January 31, 1910.

${ }^{33}$ Zemshchina, no. 195, January 31, 1910.
} 
your mistakes. Do not fish for secret information. Those who give it know why they give it to you. You should not accept this information. ${ }^{34}$

However, despite the conversation, the Information Bureau did not stop collecting secret information. The employees continued collecting secret information, although the process was not so extensive and not so open as before. On May 9, 1910, N. Griboedov instructed the employee N. Bindeman to collect information about the prospected construction of fortifications and barracks of the war ministry in Finland. However, fearing the responsibility, the employee who was charged with the task refused to do it, of which he informed his associates. In addition to the collection of classified information, which was reported to the Information Bureau free of charge, materials were listed in the expenditure statements as paid ones, in the name of some employees. The secretary of the Information Bureau, who knew about the situation, spent the funds to be accounted for and covered up the embezzlement with forgery, and the head of the Information Bureau did not raise the issue of instituting criminal proceedings against him.

It should be noted that the activities of civil servants were regulated by the current legislation, in particular, by the fifth section of the Code of Punishment "On Crimes and Misconduct in the State and Public Service." M. Shedii points out:

The Code of Punishment established rather harsh sanctions for non-execution of the highest decree or conduct with intent for any mercenary or other types of abuse of power ..., misappropriation or embezzlement of state or private property consigned for official purposes. $^{35}$

For example, if any public official received remuneration that was not statutory and was associated with violation of duties in the service, that person was subject to punishment:

In the form of imprisonment for a period from one to three years, $\ldots$ under mitigating circumstances, such an official was punished by court with severe reprimand or dismissal from office. ${ }^{36}$

One can agree with E. Golovina, who notes:

From the objective side, such abuse of power was characterized both by the actions that went beyond the competence of an official, and by those that formally complied with the sphere of his competence, but in essence contradicted the interests of the state. ${ }^{37}$

\footnotetext{
${ }^{34}$ F. 776, op. 32, d. 214, 1. 2. RGIA.

${ }^{35}$ Shedii, Corruption in Russia, 52.

${ }^{36}$ Shedii, Corruption in Russia, 53.

${ }^{37}$ Golovina, Legal Framework of the Fight against Corruption in Russia, 74.
} 
What was the case with the Information Bureau, in our opinion, was the fact of exceeding the official duties by the head of the Information Bureau and his deputy. In fact, demanding that their subordinates should collect and submit secret information, the leadership of the Information Bureau went beyond their competence and acted to the detriment of the interests of the state.

Several employees of the Bureau (V. Dobreshin, P. Kuk, and V. Myasoedov) addressed the head of the Main Department for Press Affairs A. Bel'gard with oral and written complaints about the illegal activities of N. Griboedov, but no inquiry was instituted. ${ }^{38}$

In the opinion of the author of the note on the illegal activities of the Information Bureau, the explanation of the inaction of higher authorities should be sought in the rumours that attributed the role of an attorney in A. Bel'gard's monetary affairs to N. Griboyedov. The author declared that with the help of Active State Councillor N. Khlebnikov, who had connections in financial spheres, N. Griboedov repeatedly arranged loans for A. Bel'gard. ${ }^{39}$ Until May 25, 1910, N. Khlebnikov himself was an employee of the Information Bureau with a salary of 300 roubles per month, according to the salaries of the acting assistants to the head of the Information Bureau. ${ }^{40}$

Thus, the note pointed out the illegal collection of secret information which then came into print, the appropriation of funds and the implementation of financial fraud, and also the inaction of higher authorities. According to the author of the note, the head of the Main Department for Press Affairs covered up for the head of the Information Bureau.

This situation clearly shows the state of affairs at the government institution and the attitudes of the Information Bureau executive employees. Possessing connections and authority sufficient to obtain valuable information, instead of serving the system of the state they were meant to protect and to uphold its interests in the information field, the officials used their positions for personal gain and enrichment, thus contributing to the weakening of authority of the Information Bureau and of the authorities in general.

Complaints about the activities of the Information Bureau were accepted, but judging by the lack of documents on the proceedings and by the fact that there was no replacement of management, it can be concluded that there was no official investigation. Both N. Griboedov together with his deputy and the employees who expressed dissatisfaction with the illegal activities of the leadership continued their work at the Information Bureau.

\footnotetext{
${ }^{38}$ F. 776, op. 32, d. 214, 1. 2, RGIA.

${ }^{39}$ F. 776 , op. 32, d. 214, 1. 3, RGIA.

${ }^{40}$ F. 785 , op. 1, d. 151, 1. 84, RGIA.
} 


\section{Conclusion}

The Information Bureau was established in order to provide the press with reliable information intended for publication and concerning the activities of the government, state and administrative officials and institutions, and also to provide objective coverage of social and political life in Russia and abroad, and was funded by the government. When fulfilling the order of the state to write denials and to clarify "circulating rumours and messages of Russian, non-Russian and foreign press," highranking officials of the Information Bureau collected and disseminated the information that was not subject to disclosure and in doing so they themselves became the distributors of rumours that impaired the prestige and authority of the government. That situation was possible because of the absence of any control over the activities of the Information Bureau by the higher leadership, the head of the Main Directorate for Press Affairs who was in charge of the Information Bureau as well as the lack of any well-established mechanism for controlling the institution and its employees and the lack of regulatory standards of control codified in the legislation. The combination of those factors resulted in the emergence of such situations when the state agency which had been established to support the existing political system discredited it instead.

\section{Список литературы}

Амбросьев A. В. Организационно-правовые основы деятельности Главного управления по делам печати Министерства внутренних дел Российской империи (1865-1917 гг.): автореф. дис. ... канд. юр. наук. - Академия управления министерства внутренних дел Российской Федерации, 2012. - 23 с.

Амбросьев А.В. Организационно-правовые основы деятельности осведомительного бюро при Главном управлении по делам печати Российской империи // Соблюдение законности и обеспечение правопорядка в деятельности органов внутренних дел. - Москва: Академия управления министерства внутренних дел Российской Федерации, 2011. - С. 5-9.

Амбросьев A.B. Осведомительное бюро при Главном управлении по делам печати МВД Российской империи: структура и организация деятельности // История государства и права. - 2011. - №17. - C. 30-35.

Астанин B.B. Борьба с коррупцией в России XVI - XX веков: диалектика системного подхода. - Москва: Российская криминологическая ассоциация, 2003. - 96 с.

Головина Е.И. Правовые основы борьбы с коррупцией в России в XVI - XIX вв. - Москва: МВД России, 2004. - 90 с.

Гольцов В.Б. Социальные основы предупреждения коррупции в правоохранительных органах России. - Самара: Самарская гуманитарная академия, 2014. - 108 с.

Григорьев С.И. Придворная цензура и образ верховной власти, 1831-1917. - СанктПетербург: Алетейя, 2007. - 476 с.

Егоров А.Н. Предвыборная агитация как инструмент дискредитации политического противника (по материалам выборов в Государственную думу Российской империи) // Вестник Пермского университета. - 2015. - Серия: История. - № 3 (30). - С. 170-178. 
Журавлева Я.А., Моисеев В.В. Борьба с коррупцией в России и мире. - Москва.: Филиал Московского института экономики, менеджмента и права в г. Тула, 2011. - 417 с.

Казанина Л. Ю. Столыпинские реформы в оценке российского общественного мнения (1906-1911): [к 150-летию со Дня рождения Петра Аркадьевича Столыпина]. - Москва: ACADEMIA; Академия повышения квалификации и профессиональной переподготовки работников образования, 2012. - $371 \mathrm{c}$.

Кельнер В.E. Создание и деятельность осведомительного бюро при Главном управлении по делам печати: 1906-1917 гг. // Цензура в России: история и современность. - СанктПетербург: Российская национальная библиотека, 2011. - Вып. 5. - С. 237-243.

Крылова Е.Н. Петр Дмитриевич Святополк-Мирский и деятельность Министерства внутренних дел: автореф. дис. ... канд. ист. наук. - Санкт-Петербурский государственный университет, 2006. - 23 с.

Крылова Е.Н. Формирование положительного общественного мнения о государственной власти в России в 1906-1907 гг. (на примере работы Осведомительного бюро) // Частное и общественное в повседневной жизни населения России. История и современность / отв. ред. В.А. Веременко. - Санкт-Петербург: Ленинградский государственный университет им. А.С. Пушкина, 2018. - Т. 1. - С. 162-167.

Кузовков Ю.В. История коррупции в России: В 2 т. - Москва: Анима-пресс, 2010.

Лихоманов А.В. Борьба самодержавия за общественное мнение в 1905-1907 гг. - СанктПетербург: Российская национальная библиотека, 1997. - 134 с.

Лихоманов A. В. Самодержавие в борьбе за общественное мнение в годы Первой русской революции: (Правительственная печать в 1905-1907 гг.): автореф. дис. ... канд. ист. наук. Санкт-Петербурский государственный университет, 1995. - 18 с.

Мысловский Е. Н. Коррупция в России: преступление или образ жизни? - Москва: ЭконИнформ, 2007. -238 с.

Подройкина И.А. Система уголовных наказаний в истории России и в современном зарубежном законодательстве. - Москва: Юстицинформ, 2017. - 112 с.

Стейнберг М. Великая русская революция. 1905-1921 / перевод с английского Н. Эдельмана; под научной редакцией М. Гершзона. - Москва: Институт Гайдара, 2018. $554 \mathrm{c}$.

Сторчилова Н.B. Коррупция в органах внутренних дел и ее предупреждение. - Москва: Всероссийский научно-исследовательский институт МВД России, 2012. - 124 с.

Чашин А.Н. Коррупция в России: стратегия, тактика и методы борьбы. - Москва: Дело и сервис, 2009. - 208 с.

Шевцов В.В. Правительственная периодическая печать Сибири (вторая половина XIXначало XX в.). - Томск: Томский университет, 2016. - 622 с.

Шедий М.B. Коррупция в России: опыт концептуализации и механизмы противодействия. - Орел: Орловская региональная академия государственной службы, 2011. - 144 с.

Competing voices from the Russian Revolution / ed. by M.C. Hickey. - Santa Barbara, Californiya: Greenwood, 2011. - 599 p.

Lowe N. Mastering twentieth-century Russian history. - New York: Palgrave Macmillan, 2002. $-496 \mathrm{p}$.

Rendle M. Defenders of the Motherland: the Tsarist elite in revolutionary Russia. - Oxford: Oxford university press, 2010. -274 p.

Stone B. The anatomy of revolution revisited : a comparative analysis of England, France, and Russia. - Cambridge; New York: Cambridge university press, 2014. - 529 p. 
Sunderland $W$. The baron's cloak: a history of the Russian empire in war and revolution. - Ithaca: Cornell university press, 2014. - 344 p.

Weeks T. R. Across the revolutionary divide: Russia and the USSR. 1861-1945. - Chichester: Wiley-Blackwell, 2011. - 282 p.

\section{References}

Ambros'ev, A.V. “Organizatsionno-pravovye osnovy deyatel'nosti osvedomitel'nogo byuro pri Glavnom upravlenii po delam pechati Rossiiskoi imperii" [Organizational and legal bases for the activities of the Information Bureau of the Main Directorate for Press Affairs of the Russian Empire]. In Soblyudenie zakonnosti i obespechenie pravoporyadka v deyatel'nosti organov vnutrennikh del [Observance of the law and ensurance of law and order in the activities of internal affairs authorities], 5-9. Moscow: Akademiya upravleniya Ministerstva vnutrennikh del Rossii, 2011. (In Russian)

Ambros'ev, A.V. Organizatsionno-pravovye osnovy deyatel'nosti Glavnogo upravleniya po delam pechati Ministerstva vnutrennikh del Rossiiskoi imperii (1865-1917 gg.) [Organizational and legal bases for the activities of the Main Directorate for Press Affairs of the Ministry of Internal Affairs of the Russian Empire (1865-1917)]. PhD thesis. Academy of Management of the Ministry of Internal Affairs of the Russian Federation, 2012. (In Russian)

Ambros'ev, A.V. "Osvedomitel'noye byuro pri Glavnom upravlenii po delam pechati MVD Rossiyskoy imperii: struktura i organizatsiya deyatel'nosti" [The Information Bureau of the Main Directorate for Press Affairs of the Ministry of Internal Affairs of the Russian Empire: Structure and organization of activities]. Istoriya gosudarstva i prava, no. 17 (2011): 30-35. (In Russian)

Astanin, V.V. Bor'ba s korruptsiyey v Rossii XVI - XX vekov: dialektika sistemnogo podkhoda [The fight against corruption in Russia in the $16^{\text {th }}-20^{\text {th }}$ centuries: dialectics of system approach]. Moscow: Rossiiskaya kriminologicheskaya assotsiatsiya, 2003. (In Russian)

Chashin, A.N. Korruptsiya v Rossii: strategiya, taktika i metody bor'by [Corruption in Russia: strategy, tactics and methods of fight]. Moscow: Delo i servis, 2009. (In Russian)

Egorov, A.N. "Predvybornaya agitatsiya kak instrument diskreditatsii politicheskogo protivnika (po materialam vyborov v Gosudarstvennuyu dumu Rossiiskoi imperii)" [Pre-election campaign as a tool to discredit a political opponent (based on the materials of elections to the State Duma of the Russian Empire]. Vestnik Permskogo universiteta. Seriya: Istoriya, vol. 30, no. 3 (2015): 170-78. (In Russian)

Golovina, E.I. Pravovyye osnovy bor'by s korruptsiyey v Rossii v XVI - XIX vv. [Legal framework of the fight against corruption in Russia in the $16^{\text {th }}-19^{\text {th }}$ centuries]. Moscow: Ministerstvo vnutrennikh del Rossii, 2004. (In Russian)

Gol'tsov, V.B. Sotsial'nye osnovy preduprezhdeniya korruptsii v pravookhranitel'nykh organakh Rossii [Social foundations for the prevention of corruption in law enforcement agencies of Russia]. Samara: Samarskaya gumanitarnaya akademiya, 2014. (In Russian)

Grigor'ev, S.I. Pridvornaya tsenzura i obraz verkhovnoy vlasti, 1831-1917 [Court censorship and the image of supreme power, 1831-1917]. St Petersburg: Aleteya, 2007. (In Russian)

Hickey, M.C., ed. Competing Voices from the Russian Revolution. Santa Barbara, Calif.: Greenwood, 2011.

Kazanina, L.Yu. Stolypinskie reformy v otsenke rossiiskogo obshchestvennogo mneniya (19061911): [k 150-letiyu so Dnya rozhdeniya Petra Arkad'evicha Stolypina] [Stolypin reforms in the assessment of Russian public opinion (1906-1911): [to the $150^{\text {th }}$ anniversary of the birth of Petr 
Arkad'evich Stolypin]]. Moscow: ACADEMIA; Akademiya povysheniya kvalifikatsii i professional'noi perepodgotovki rabotnikov obrazovaniya, 2012. (In Russian)

Kel'ner, V.E. "Sozdanie i deyatel'nost' osvedomitel'nogo byuro pri Glavnom upravlenii po delam pechati: 1906-1917 gg." [Establishment and operation of the Information Bureau of the Main Directorate for Press Affairs: 1906-1917]. In Tsenzura v Rossii: istoriya i sovremennost' [Censorship in Russia: history and the present]. Issue 5, 237-43. St Petersburg: Rossiiskaya natsional'naya biblioteka, 2011. (In Russian)

Krylova, E.N. "Formirovaniye polozhitel'nogo obshchestvennogo mneniya o gosudarstvennoi vlasti v Rossii v 1906-1907 gg. (na primere raboty Osvedomitel'nogo byuro)" [Forming positive public opinion about the government authorities of Russia in 1906-1907 (based on the work of the Information Bureau)]. In Chastnoye $i$ obshchestvennoye $v$ povsednevnoi zhizni naseleniya Rossii. Istoriya $i$ sovremennost' [Private and public affairs in the daily life of the population of Russia. History and modernity], edited by V.A. Veremenko, vol. 1, 162-67. St Petersburg: Leningradskii gosudarstvennyi universitet imeni A.S. Pushkina, 2018. (In Russian)

Krylova, E.N. Petr Dmitrievich Svyatopolk-Mirskii i deyatel'nost' Ministerstva vnutrennikh del [Petr Dmitrievich Svyatopolk-Mirsky and the activities of the Ministry of Internal Affairs]. PhD thesis. St Petersburg State University, 2006. (In Russian)

Kuzovkov, Yu.V. Istoriya korruptsii v Rossii [History of corruption in Russia]. 2 vols. Moscow: Anima-press, 2010. (In Russian)

Likhomanov, A.V. Samoderzhavie v bor'be za obshchestvennoe mnenie v gody Pervoi russkoi revolyutsii: (Pravitel'stvennaya pechat' v 1905-1907 gg.) [Autocracy in the struggle for public opinion during the First Russian Revolution (Governmental press in 1905-1907)]. PhD thesis. St Petersburg State University, 1995. (In Russian)

Likhomanov, A.V. Bor'ba samoderzhaviya za obshchestvennoe mnenie v 1905-1907 gg. [The struggle of autocracy for public opinion in 1905-1907]. St Petersburg: Rossiiskaya natsional'naya biblioteka, 1997. (In Russian)

Lowe, N. Mastering Twentieth-Century Russian History. New York: Palgrave Macmillan, 2002.

Myslovskii, E.N. Korruptsiya v Rossii: prestuplenie ili obraz zhizni? [Corruption in Russia: a crime or a way of life?]. Moscow: Ekon-Inform, 2007. (In Russian)

Podroikina, I.A. Sistema ugolovnykh nakazanii v istorii Rossii $i v$ sovremennom zarubezhnom zakonodatel'stve [The system of criminal penalties in the history of Russia and in modern foreign legislation]. Moscow: Yustitsinform, 2017. (In Russian)

Rendle, M. Defenders of the Motherland: The Tsarist Elite in Revolutionary Russia. Oxford: Oxford University Press, 2010.

Shedii, M.V. Korruptsiya v Rossii: opyt kontseptualizatsii i mekhanizmy protivodeistviya [Corruption in Russia: the experience of conceptualization and counteraction mechanism]. Orel: Orlovskaya regional'naya akademiya gosudarstvennoi sluzhby, 2011. (In Russian)

Shevtsov, V.V. Pravitel'stvennaya periodicheskaya pechat' Sibiri (vtoraya polovina XIXnachalo $X X$ v.) [Governmental periodical press of Siberia (second half of the $19^{\text {th }}$ - early $20^{\text {th }}$ century)]. Tomsk: Tomskii universitet, 2016. (In Russian)

Steinberg, M. Velikaya russkaya revolyutsiya, 1905-1921 [The Russian Revolution, 1905 1921]. Translated by Nikolai Edel'man. Edited by Mikhail Gershzon. Moscow: Institut Gaidara, 2018. (In Russian)

Stone, B. The Anatomy of Revolution Revisited: A Comparative Analysis of England, France, and Russia. Cambridge; New York: Cambridge University Press, 2014. 
Storchilova, N.V. Korruptsiya v organakh vnutrennikh del i ee preduprezhdenie [Corruption in the internal affairs bodies and its prevention]. Moscow: Vserossiiskii nauchno-issledovatel'skii institut Ministerstva vnutrennikh del Rossii, 2012. (In Russian).

Sunderland, W. The Baron's Cloak: A History of the Russian Empire in War and Revolution. Ithaca: Cornell University Press, 2014.

Weeks, T.R. Across the Revolutionary Divide: Russia and the USSR. 1861-1945. Chichester: Wiley-Blackwell, 2011.

Zhuravleva, Ya.A., and V.V. Moiseev. Bor'ba s korruptsiei v Rossii i mire [Fight against corruption in Russia and in the world]. Moscow: Filial Moskovskogo instituta ekonomiki, menedzhmenta i prava v gorode Tula, 2011. (In Russian) 